Original Article

\title{
High dilutions of Euphorbia tirucalli L. (AVELOZ) modify the viability and glycolitic metabolism of cell lines
}

\author{
Carolina Lessa Aquinoํㅡㄹ Glauce Moreno Barbosa ${ }^{1}$, Gleyce Moreno Barbosa ${ }^{1}$, \\ Marcia Cristina Braga Antunes Varricchioํㅜ, Venício Feo Veiga ${ }^{2}$, Ricardo \\ Kuster $^{3}$, Patrícia Zancan ${ }^{4}$, Mauro Sola-Penna ${ }^{5}$, Carla Holandino(PhD) ${ }^{6 *}$.
}

1Multidisciplinary Laboratory of Pharmaceutical Sciences, Department of Medicines, Faculty of Pharmacy, Center for Health Sciences, Federal University of Rio de Janeiro. Rio de Janeiro, Brazil.

2Institute of Microbiology Professor Paulo de Góes, Center for Health Sciences, Federal University of Rio de Janeiro, Rio de Janeiro, Brazil.

${ }^{3}$ Laboratory of Phytochemistry of Natural Products, Nucleus of Research on Natural Products, Center of Health Sciences, Federal University of Rio de Janeiro, Rio de Janeiro, Brazil.

4Laboratory of Enzymology and Control of Metabolism (LabECoM), Department of Drugs, Faculty of Pharmacy, Center of Health Sciences, Federal University of Rio de Janeiro, Rio de Janeiro, Brazil.

\begin{abstract}
The latex of Euphorbia tirucalli L. (Aveloz) is popularly used to treat cancers from diverse sources such as: breast, prostate, lung and kidney. Furthermore, high dilutions of this latex (latex-HDs) have been successfully used in the treatment of tumors, although the mechanisms involved in this antitumoral activity are not yet known. The present study aimed to investigate the cytotoxic effects of latex-HDs in 2 human cell lines, including non-tumoral melanocytes (MelanA line) and human breast cancer cells (MCF7 line). Latex-HDs were obtained through the interaction of two procedures: 1:100 dilution in mass and agitation, using 2 solvents, water and 70\% ethanol in homeopathic preparations 5, 15 and $30 \mathrm{cH}$, following the Brazilian Homeopathic Pharmacopeia. Cell lines were incubated with $1 \%$ and $10 \%$ of latex-HDs for 24 hours. Controls treated with similar preparations without latex were incubated under the same conditions. Cell viability was analyzed by MTT assay and morphological features were assessed by May-Grunwald-Giemsa method. Cell ultrastructure was analyzed by transmission electron microscopy. Metabolic alterations were detected by spectrophotometric assay for the enzyme 6-phosphofructo-1-kinase (PFK-1) activity. 1\% of ethanolic latex-HDs induced no alterations in MelanA cells viability; however Aveloz $15 \mathrm{cH}$ induced an increase in MCF7 cells viability. After aqueous treatment, MelanA cells viability decreased in almost all systems, whereas in MCF7 cells, an increase was detected in dynamized water systems and Aveloz $15 \mathrm{cH}$. However, only water $15 \mathrm{cH}$ increased cell viability in comparison to control and non-dynamized water. No alterations in MCF7 morphology and ultrastructure were visualized through light microscopy or electronic microscopy, respectively. Interesting results were detected when we studied the glycolytic metabolism of both cells, supporting evidences that HDs interfere in the metabolism of cell lines. Further studies are needed to better understand the mechanisms involved in this in vitro biological response to HDs.
\end{abstract}

Keywords: Euphorbia tirucalli L.; Aveloz; PFK-1; High Dilutions; Cell metabolism 


\section{Introduction}

Euphorbia tirucalli L., popularly known as aveloz, is a succulent shrub, most common in equatorial regions, like Africa, Asia and Latin America, but also presents universal distribution around the world. Aveloz is found in Brazil mainly in Pernambuco, Ceará, Bahia, Rio de Janeiro and the coast of São Paulo [1].

Latex of Aveloz is used orally or topically in traditional medicine and is popularly known as an antitumoral agent (breast, prostate, lung, kidney) not only in Brazil, but in several other countries. According to literature, the latex may have dual behavior, activating or inhibiting tumoral events [25]. However, there are few reports discussing these mechanisms.

High dilutions (HDs) of Aveloz have been used by Brazilian homeopathic physicians as complementary therapy in several settings, including veterinary treatments, neoplasias and immunodeficiency related to viruses upon approval by ethics committees [6].

In Brazil, homeopathy is obtaining increasing institutional recognition among physicians and users of public and private health services. Such a fact encourages Brazilian researchers to develop experimental and clinical models which may contribute to the elucidation of the mechanism(s) of action of high-diluted medicines [7-10]. In previous studies, it has been shown that modulation of glycolitic enzymes, such as 6-phosphofructo-1-kinase (PFK-1), in tumoral cells may be a mechanism in antineoplastic activity, since energy metabolism in neoplastic cells is often altered [11-12]. Indeed, glycolysis acts as the primary energy source in cancer cells, exceeding the capacity of mitochondrial oxidative energetic metabolism [13].

In the present work, we compared biochemical effects induced by HDs of Aveloz in the homeopathic preparations $5 \mathrm{cH}, 15 \mathrm{cH}$ and $30 \mathrm{cH}$ on tumoral (human breast cancer - MCF7) and non-tumoral (melanocytes - MelanA) cell line cultures. These preparations were chosen in order to evaluate biological effects in the presence $(5 \mathrm{cH})$ and absence (15 and $30 \mathrm{cH})$ of active substrate, as in the latter Avogadro's number is surpassed. Alterations in cell viability, morphology and glycolitic metabolism of these cell lines were evaluated by different assays and showed significant metabolic alterations induced by HDs.

\section{Materials and Methods}

\section{Materials}

Homeopathic solutions were prepared following Brazilian Homeopathic Pharmacopeia [14] for insoluble active substances, characterized by 3 independent triturations in lactose until $3 \mathrm{cH}$, followed by solubilization in $20 \%$ ethanol and agitation to reach $4 \mathrm{cH}$. $5 \mathrm{cH}$ was prepared by adding 1 part of $4 \mathrm{cH}$ in 99 parts of solvent. This procedure of dilution 1:100, and mechanical sucussion (Denise 10-50, AUTIC) was repeated until $30 \mathrm{cH}$ was reached. Solutions were prepared with 2 different solvents, namely distilled water (aqueous latexHDS) and 70\% ethanol v/v (ethanolic latex-HDS).

In order to register some occasional chemical effect of aveloz latex or systematic experimental errors on dilutions, an equivalent set of control samples not containing the active principle was prepared under the same conditions. All solutions (test and control) were filtered through a sterile membrane $(0.22 \mu \mathrm{m})$, in sterile conditions, before the in vitro assays.

In all experiments, MelanA and MCF7 cell lines were grown in monolayers at $37^{\circ} \mathrm{C}$ in culture flasks containing Dulbecco's modified Eagle's medium (DMEM) supplemented with $10 \%$ of fetal bovine serum (FBS-Gibco, Invitrogen, USA) and $0.3 \mathrm{~g} / \mathrm{L}$ glutamine. $\mathrm{pH}$ control was warranted by the addition of $3 \mathrm{~g} / \mathrm{L} \quad N$-(2-hydroxyethyl)-piperazine- $N$ (2-ethanesulfonic acid) (HEPES), and $0.2 \mathrm{~g} / \mathrm{L}$ $\mathrm{NaHCO}_{3}$ to the medium, as previously described [15]. Initial inoculum was $5 \times 10^{4}$ cells $/ \mathrm{mL}$, which was subcultured every 2 or 3 days and maintained in log-phase growth.

\section{Cytotoxicity assay}

Confluent MCF7 and MelanA cells were seeded in 96 well plates with $1 \%$ and $10 \%$ of latex-HDs or control solutions (dynamized and non-dynamized solvents) and kept in incubation for 24 hours [16]. At the end of treatments, $20 \mu \mathrm{L}$ of $5 \mathrm{mg} / \mathrm{mL}$ solution of tetrazolium reagent (3,4,5-dimethiazol-2,5diphenyl-tetrazolium bromide, Sigma) were added to each well. Culture plates were incubated for further 3 hours at $37^{\circ} \mathrm{C}$ in the absence of light. Supernatant was removed and formazan crystals were dissolved with $200 \mu \mathrm{L}$ of dimethylsulfoxide. Absorbance was measured in each well in dual wave-length, according to Mosmann [17].

\section{Morphological changes assay}

Morphological features of treated and untreated cells were assessed through May-Grunwald-Giemsa method. At least 200 cells in each preparation were examined with a light microscope (AXIOPLAN II/ZEISS). For analysis of cellular alterations, 2 separate experiments were performed [18].

\section{Enzyme activity measurements}

Metabolic alterations were detected through spectrophotometric assay of the activity of 6phosphofructo-1-kinase (PFK-1), as previously described [19]. Briefly, cells were lysed in $10 \mathrm{mM}$ $\mathrm{K}_{2} \mathrm{HPO}_{4}\left(10^{5} \mathrm{cell} / \mathrm{mL}\right)$ after a freeze-thaw cycle. An aliquot $(100 \mu \mathrm{L})$ was used to assay enzyme activity 
in a medium containing $50 \mathrm{mM}$ Tris- $\mathrm{HCl}(\mathrm{pH} 7.4), 5$

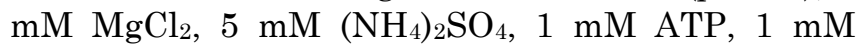
fructose-6-phosphate, $2 \mathrm{mM} \mathrm{NADH}, 2 \mathrm{U} / \mathrm{mL}$ aldolase, $2 \mathrm{U} / \mathrm{mL}$ triose phosphate isomerase and 2 U/ml $\alpha$-glycerophosphate dehydrogenase. Fructose1,6-biphosphate formed through PFK-1 catalysis was lysed by aldolase in dihidroxycetone-phosphate and glyceraldehyde-3-phosphate, which was converted in dihidroxycetone-phosphate by triosephosphate dehydrogenase. Dihidroxycetonephosphate was then reduced in $\alpha$-glycerophosphate by $\alpha$-glycerophosphate dehydrogenase coupled with the oxidation of $\mathrm{NADH}$ which is followed spectrophotometrically at $340 \mathrm{~nm}$. The oxidation of $\mathrm{NADH}$ occurred in parallel to PFK-1 activity and was used to determine the latter.

\section{Electron microscopy}

Ultrastructural alterations in MCF7 cells after incubation with ethanolic latex-HDs were evaluated by transmission electron microscopy (TEM). Cells were first centrifuged and re-suspended in a $2.5 \%$ glutaraldehyde solution. After 2 hours incubation in this solution, cells were washed in $0.1 \mathrm{M}$ cacodylate buffer ( $\mathrm{pH} 7.2$ ) containing $0.2 \mathrm{M}$ sucrose and were post-fixed in 1\% osmium tetroxide for $45 \mathrm{~min}$. After fixation, they were pre-included in $1.5 \%$ agar, dehydrated with ethanol and acetone, and embedded in Epon resin [20]. Ultrathin sections were prepared with a diamond knife in an ultramicrotome (KLB), collected in 300 mesh cooper grids, counterstained with uranyl acetate and lead citrate and examined under TEM operating at $80 \mathrm{kV}$ (Morgani 268/FEI).

\section{Statistical analysis}

Student's test was used to evaluate the significance of results. In all analyses, confidence interval was $95 \% ; p$ values less than 0.05 were considered significant.

\section{Results and Discussion}

Results obtained by MTT assay showed significant fall $(p<0.05)$ in cell viability when treated with $10 \%$ of non-dynamized ethanol, induced by the toxic effects of this solvent (Figures 1, 2). For MelanA cells we detected a decrease in cell viability induced by all dynamized solutions in comparison to nondynamized ethanol and significant differences $(p<0.05)$ when we compared ethanolic latex-HDs to the respective dynamized ethanol solutions (Figure 1). The same profile was observed in MCF7 cells, except dilution $5 \mathrm{cH}$, that induced similar rates of cell viability (Figure 2 ).

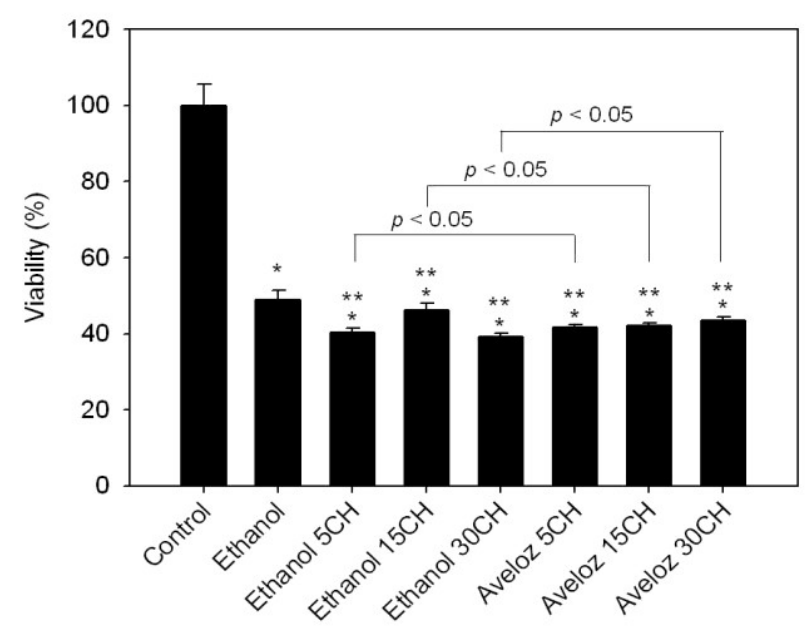

Figure 1: Viability of MelanA cells incubated 24 hours with $10 \%$ ethanolic latex-HDs and respective controls. Values are means $\pm \mathrm{SE}$ of 3 independent experiments performed in quintuplicates $(n=3)$. *Significant difference as compared to control. **Significant difference as compared to ethanol solvent.

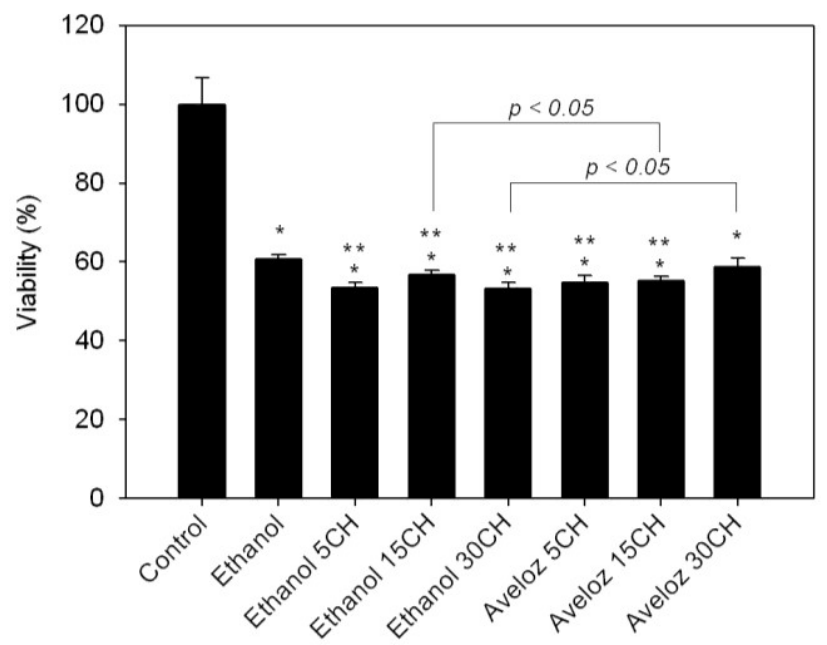

Figure 2: Viability of MCF7 cells incubated 24 hours with $10 \%$ ethanolic latex-UDS and respective controls. Values are means $\pm \mathrm{SE}$ of 3 independent experiments performed in quintuplicates $(n=3)$. *Significant difference as compared to control. **Significant difference as compared to ethanol solvent.

Assay of morphological changes showed damage caused by ethanol on both cell lines, confirming MTT result (Figure 3). MelanA cells were so sensitive to this solvent that we were not able to perform this assay successfully. 
The higher toxicity caused by ethanol led us to decrease this solvent concentration to $1 \%$. With lower concentrations of ethanol we ensured cellular integrity and morphological alterations were not detected by neither optical nor electronic microscopy (data not shown). No cytotoxic effects were detected in MelanA cells (Figure 4). However in MCF7 line, we observed that Aveloz $5 \mathrm{cH}$ increased viability when compared to untreated cells and nondynamized ethanol. Ethanolic latex-HDs at $15 \mathrm{cH}$ increased MCF7 viability in comparison to nondynamized ethanol and dynamized ethanol in the respective dilution (Figure 5, $p<0.05$ ). Nevertheless, MCF7 cells treated with non-dynamized ethanol, dynamized ethanol and ethanolic latex-HDs did not show morphological nor ultrastructural damage (data not shown). In the light of the results presented above, we may say that the effects observed might not be due exclusively to the solvent, but to the dilution procedure.

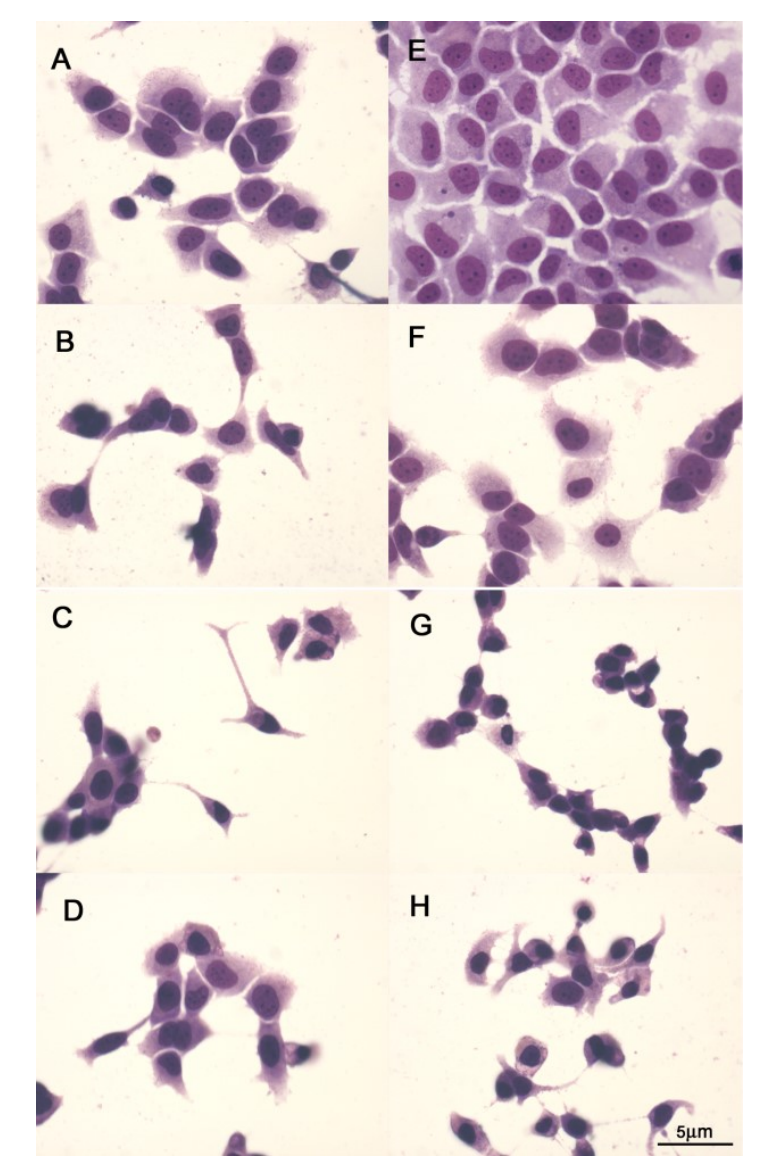

Figure 3: Morphology of MCF7 cells incubated with $10 \%$ ethanolic latex-HDs. A) Ethanol $70 \%$, B) Ethanol $5 \mathrm{cH}, \mathrm{C}$ ) Ethanol $15 \mathrm{cH}, \mathrm{D})$ Ethanol $30 \mathrm{cH}, \mathrm{E})$ Control, F) Aveloz 5cH, G) Aveloz 15cH, H) Aveloz $30 \mathrm{cH}$. Panels are representative figures of a series of 2 independent experiments. Scale bar: $5 \mu \mathrm{m}$.

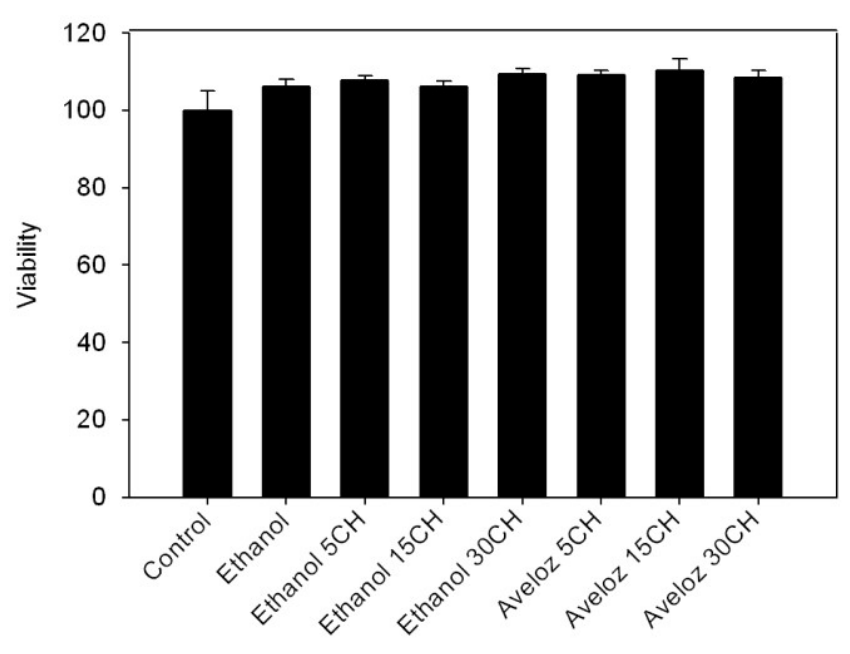

Figure 4: Viability of MelanA cells incubated 24 hours with $1 \%$ ethanolic latex-HDs and respective controls. Values are means $\pm \mathrm{SE}$ of 3 independent experiments performed in quintuplicates $(n=3)$. No significant difference was induced by tested solutions.

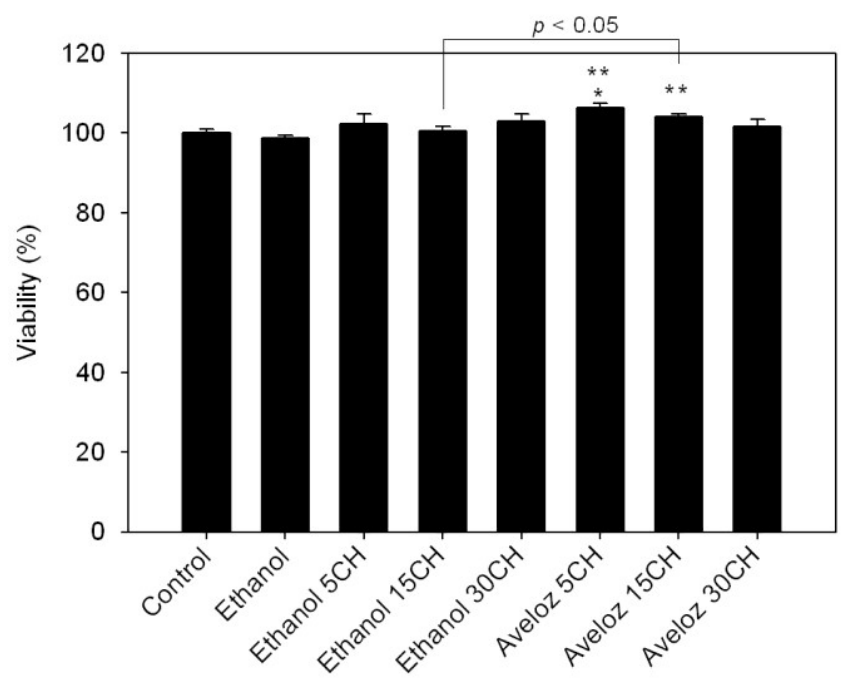

Figure 5: Viability of MCF7 cells incubated 24 hours with $1 \%$ ethanolic latex-HDs and respective controls. Values are means $\pm \mathrm{SE}$ of 3 independent experiments performed in quintuplicates $(n=3)$. * Significant difference as compared to control. ** Significant difference as compared to ethanol solvent.

Aqueous latex-HDs at $10 \%$ induced significant fall in non-tumoral melanocytes viability according to MTT assay (Figure 6).

This phenomenon occurred in non-dynamized water and all dynamized systems, except for latex-HDs 
$30 \mathrm{cH}(p<0.05)$. On the other hand, in breast cancer cells, a different pattern of response was detected since it was possible to register significant differences among treatments $(p<0.05)$. Dynamized water systems and latex-HDs $15 \mathrm{cH}$ increased MCF7 cells viability compared to non-dynamized water; with dynamized water $15 \mathrm{cH}$, this increase was also significant $(p<0.05)$ regarding untreated cells (Figure 7). Optical microscopy of both cell lines after aqueous treatment did not show alterations with any treatment (data not shown).

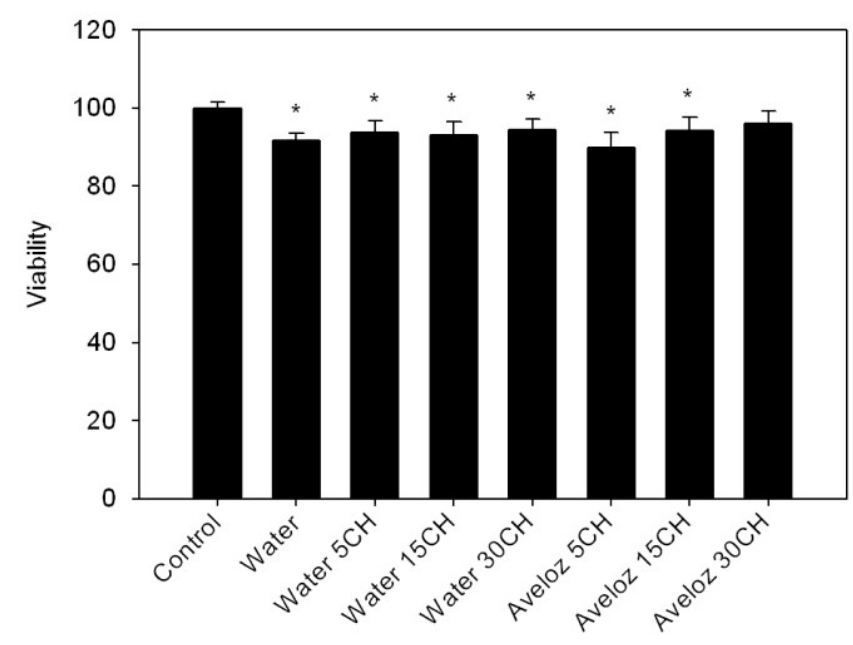

Figure 6: Viability of MelanA cells after incubation 24 hours with $10 \%$ aqueous latex-HDs and respective controls. Values are means $\pm \mathrm{SE}$ of 3 independent experiments performed in quintuplicates $(\mathrm{n}=3)$. ${ }^{*}$ Significant difference as compared to control.

We could not correlate these MTT results to cellular morphology as analyzed by optical and electronic microscopy. Since MTT measures mithocondrial activity [15], we decided to search for another metabolic parameter such as glycolitic metabolism. When MelanA cells were treated with aqueous solutions, significant differences were not detected among cellular groups (Figure 8, $p>0.05$ ).

However, after $1 \%$ dynamized ethanol $(5 \mathrm{cH}, 30 \mathrm{cH})$ and ethanolic latex-HDs at $5 \mathrm{cH}$, MelanA PFK-1 activity decreased $(p<0.05)$ in comparison to nondynamized ethanol and untreated cells (Figure 9).

Moreover, ethanolic latex-HDs $30 \mathrm{cH}$ were significantly different from dynamized ethanol $30 \mathrm{cH}$. This result shows that, despite the fact that dynamized ethanol $30 \mathrm{cH}$ and latex-HDs $30 \mathrm{cH}$ are chemically equal, MelanA cells responded to treatments in different ways. These cell alterations detected in both PFK activity and cell viability induced by ethanolic latex-HDs at $5 \mathrm{cH}$, which presented effects on both PFK activity and cell viability, could be attributed to a low pharmacological dose of some components of Aveloz, such as phorbol esters. The same does not apply to preparation $30 \mathrm{cH}$, since no molecules are present in it.

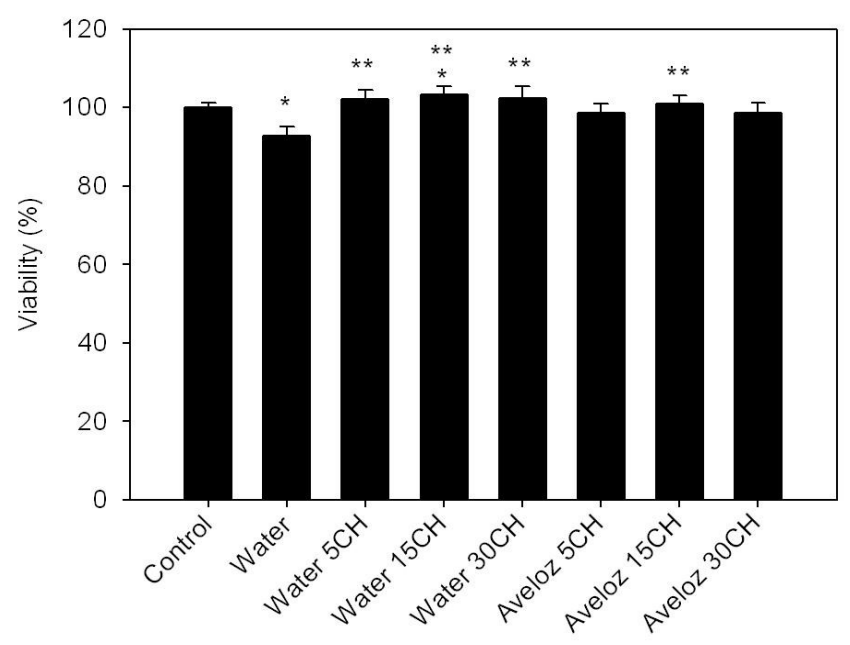

Figure 7: Viability of MCF7 cells after incubation 24 hours with $10 \%$ aqueous latex-HDs solutions and respective controls. Values are means $\pm \mathrm{SE}$ of 3 independent experiments performed in quintuplicates $(\mathrm{n}=3)$. "Significant difference as compared to control. "* Significant difference as compared to water.

This different pattern of response between chemically equal solutions was also seen in MCF7 cells. When we analyzed this tumoral glycolitic metabolic aspect, we observed that dynamized water systems and aqueous latex-HDs $30 \mathrm{cH}$ decreased MCF7 PFK-1 activity $(p<0.05$, Figure 10). With dynamized water $(15 \mathrm{cH}, 30 \mathrm{cH})$ this decrease also applied to MCF7 control cells $(p<0.05)$. However, ethanolic solutions (dynamized and non-dynamized) did not alter PFK-1 activity (Figure 11, $p>0.05$ ).

Although we could not correlate results obtained through measurement of MelanA cells PFK-1 activity through MTT after ethanolic treatments, we can conclude that dynamized water systems modified glycolytic and mithocondrial metabolism of MCF7 cell line. To emphasize these interesting results, we drew a figure where this aspect can be more easily visualized (Figure 12A-B). 


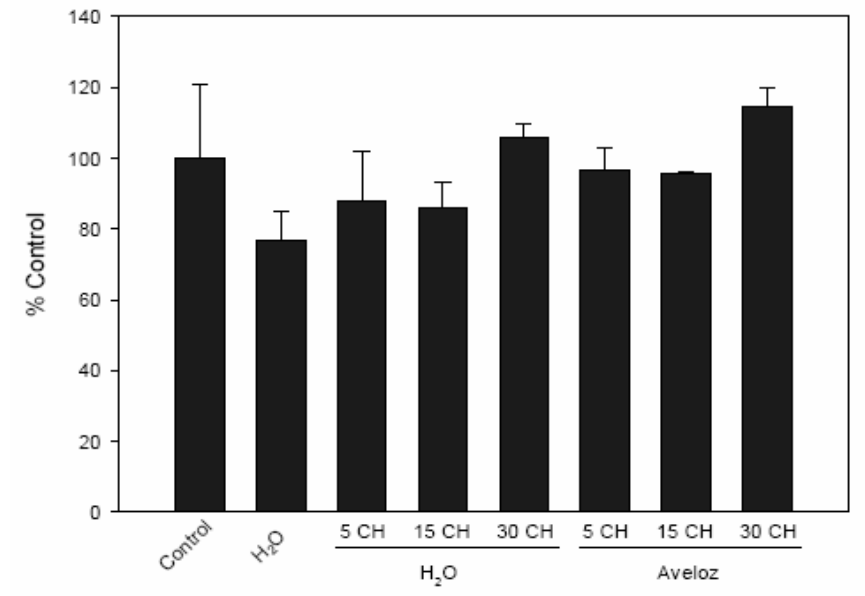

Figure 8: Activity of enzyme PFK-1 of MelanA cells incubated with $10 \%$ aqueous latex-HDs 24 hours. Values are means $\pm \mathrm{SE}$ of at least 3 independent experiments performed in duplicates $(n=3)$. No significant difference was induced by tested solutions.

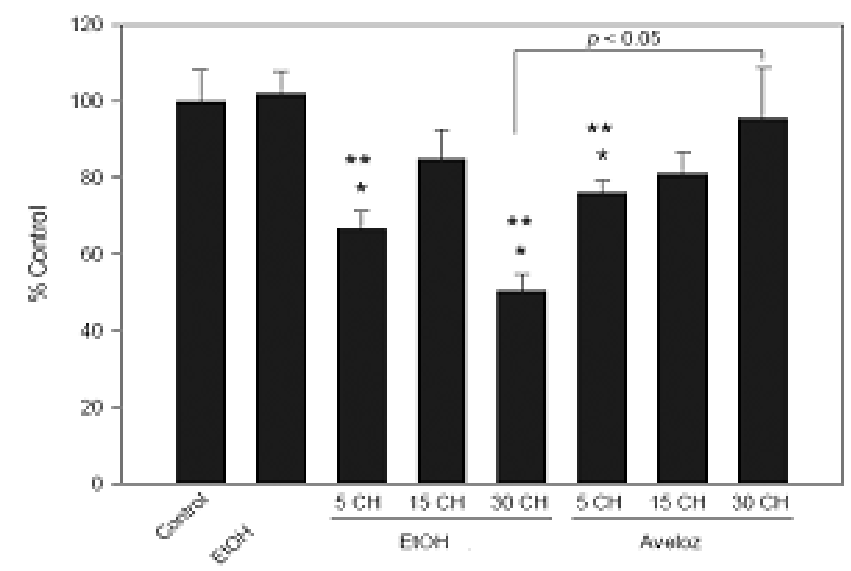

Figure 9: Activity of enzyme PFK-1 of MelanA cells incubated with $1 \%$ ethanolic latex-HDs 24 hours. Values are means $\pm \mathrm{SE}$ of at least 3 independent experiments performed in duplicates $(\mathrm{n}=3)$. *Significant difference as compared to control. $* *$ Significant difference as compared to ethanol solvent.

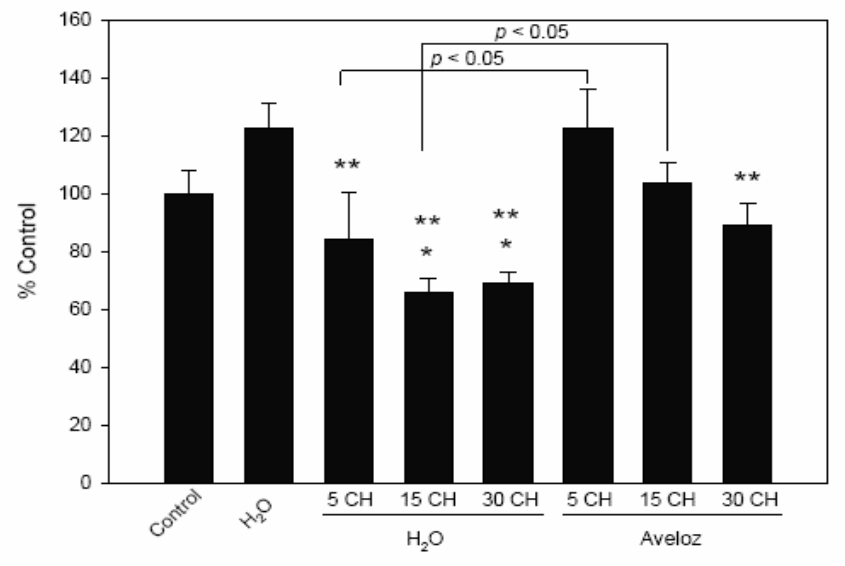

Figure 10: Activity of enzyme PFK-1 of MCF7 cells incubated with $10 \%$ aqueous latex-HDs 24 hours. Values are means $\pm \mathrm{SE}$ of at least 3 independent experiments performed in duplicates $(\mathrm{n}=3)$. *Significant difference as compared to control. ** Significant difference as compared to water solvent.

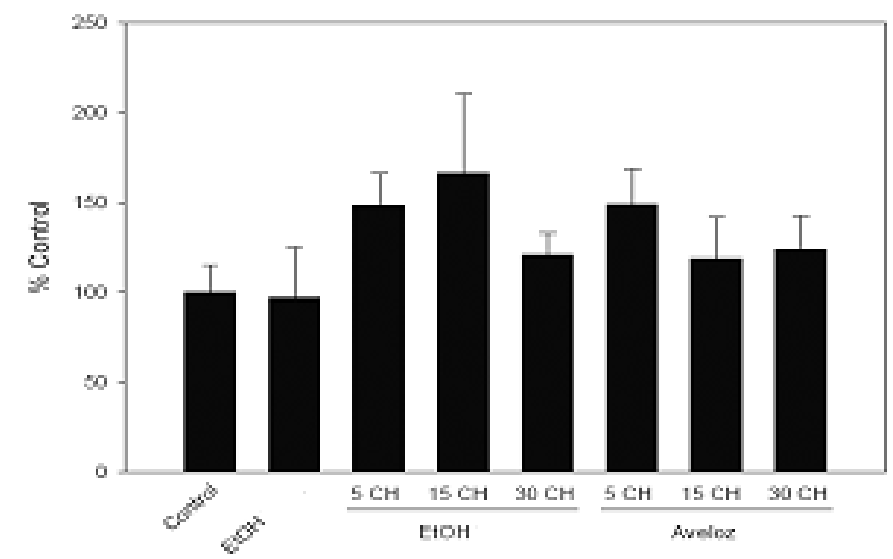

Figure 11: Activity of PFK-1 of MCF7 cells incubated with $1 \%$ ethanolic latex-HDs 24 hours. Values are means $\pm \mathrm{SE}$ of at least 3 independent experiments performed in duplicates $(\mathrm{n}=3)$. No significative difference was induced by tested solutions. 

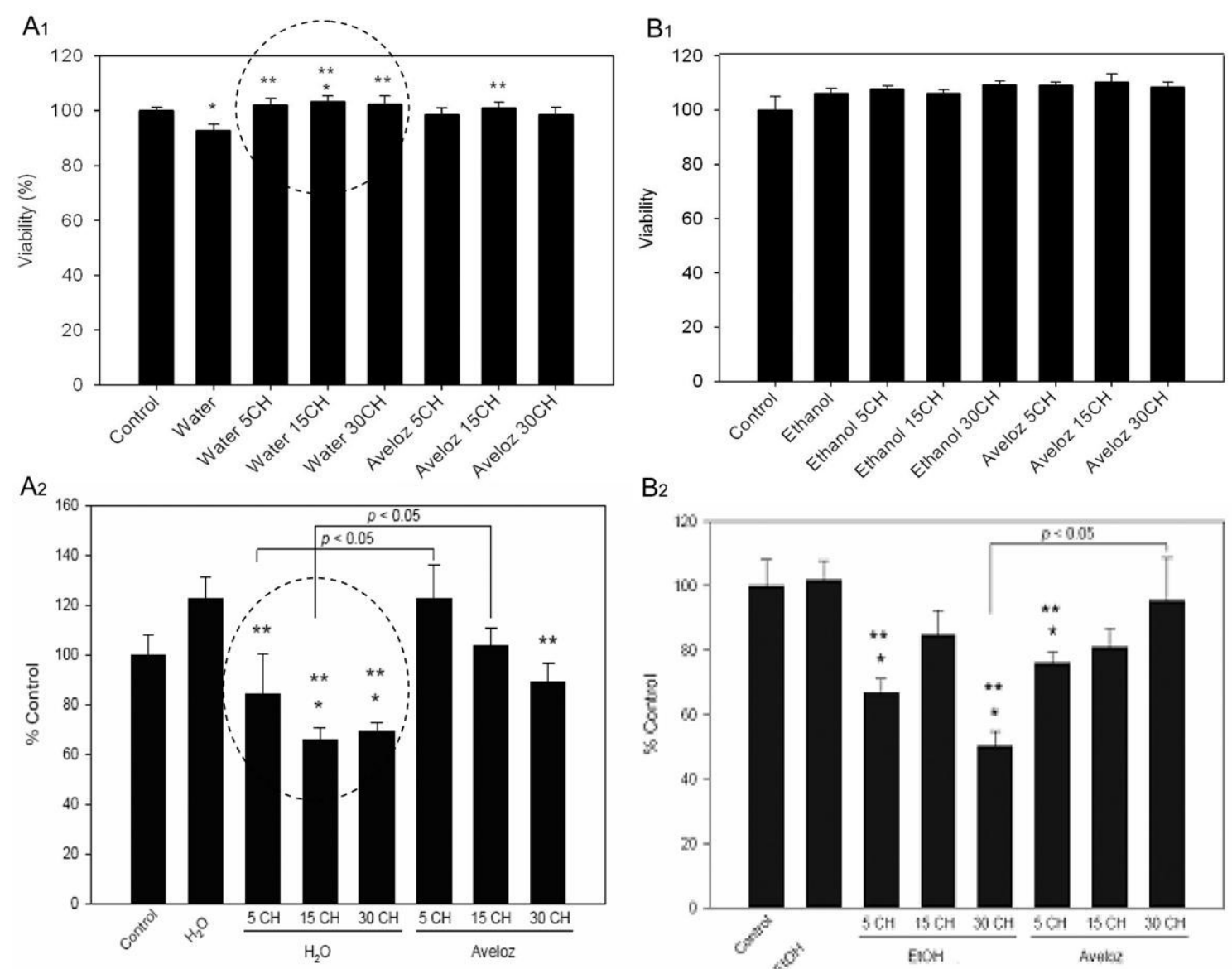

$\mathrm{B}_{2}$

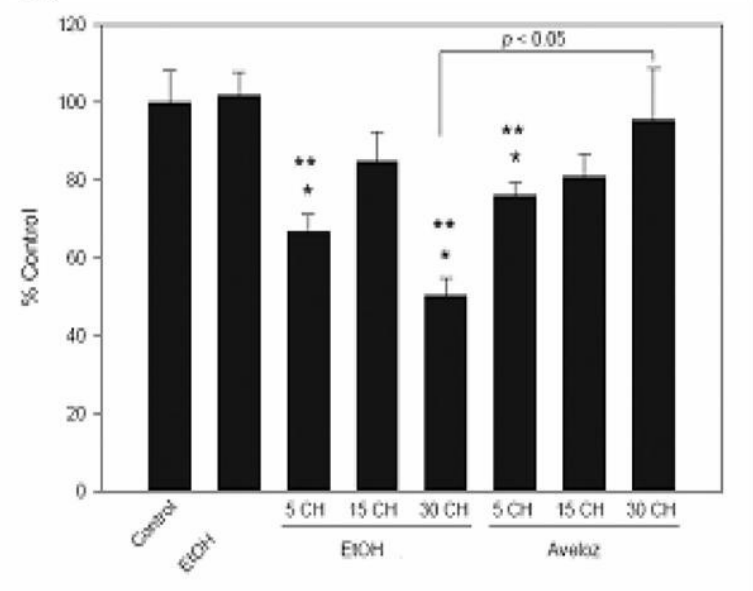

Figure 12: Alterations in mithocondrial activity (A1) and PFK-1 activity (A2) in MCF7 cells after aqueous treatment. Alterations in mithocondrial activity (B1) and PFK-1 activity (B2) in MelanA cells after ethanolic treatment. Values are means $\pm \mathrm{SE}$ of at least 3 independent experiments performed in duplicates $(\mathrm{n}=3)$. *Significant difference as compared to control. ${ }^{* *}$ Significant difference as compared to water or ethanol solvent.

We could not correlate the results obtained in the present study to dilutions, solvents nor cellular metabolism. This difficulty may be attributed to a specific behavior of high-diluted systems. However, this study brings new interesting results and signals that much work has to be done before these curious aspects of dynamized systems can be fully understood.

\section{Conclusions}

The results obtained in the present study led us to notice an interesting aspect of dynamized systems: are homeopathic solutions able to interfere in the biochemical features of different kinds of cells, even in the absence of active molecules? In the light of this, is it possible that cell lines 'understand' homeopathic information in different ways? Unfortunately, we cannot answer these questions yet, but new experiments are under development to further investigate this intriguing result.

\section{References}

[1] Jurberg P, Cabral Neto JB, Schall VT. Molluscicide activity of the "AVELÓS" plant (Euphorbia tirucalli, L.) on Biomphalaria glabrata, the mollusk vector of Schistosomiasis. Mem Inst Oswaldo Cruz. 1985; 80(4): 423-427.

[2] Furstenberger G, Hecker E. On the active principles of the Euphorbiaceae XII. Highly unsaturated irritant diterpene esters from Euphorbia tirucalli originating from Madagascar. J Nat Prod. 1986; 49: 386-397.

[3] Sugiura M, Imai S, Sakurada K, Myiazaki T, Osato T. Cryptic dysfunction of cellular immunity in asymptomatic human immunodeficiency virus (HIV) carriers and its actualization by an environmental immunosuppressive factor. In vivo. 1994; 8: 10191022.

[4] Betancur-Galvis LA, Morales GE, Forero JE, Roldan J. Cytotoxic and antiviral activities of colombian medicinal plant extracts of the Euphorbia genus. Mem Inst Oswaldo Cruz. 2002; 97(4): 541546. 
[5] Bosch CA. Is endemic Burkitt's lymphoma an alliance between three infections and a tumour promoter? Lancet Oncol. 2004; 5: 738-746.

[6] Varricchio MCBN. Estudos integrados: biotecnologia, toxicologia, metabólitos especiais e atividade antitumoral de Euphorbia tirucalli Lineu [Dissertation Master]. Rio de Janeiro: Postgraduate Program in Vegetal Biotechnology, UFRJ; 2005.

[7] Bonamim LV, Martinho KS, Nina AL, Caviglia F, Do Rio RGW. Very high dilutions of dexamethasone inhibit its pharmacological effects in vivo. British Homeopathic Journal. 2001; 90: 198203.

[8] Aquino CL, Varricchio MCBN, Moreno G, Veiga VF, Zancan P, Sola-Penna M, Kuster RM, Holandino C. Cytotoxicity and biochemical alterations induced by Euphorbia tirucalli Lineu in tumoral and non tumoral cell lines. Proceedings of the 6th International Congress of Pharmaceutical Sciences; 2007 Sep 2-5; Ribeirão Preto. Brasil. Ribeirão Preto: CIFARP; 2007. p 93.

[9] Siqueira CM, Costa B, Amorim AM, Gonçalvez M, Veiga VF, Lyrio C, Couceiro, JN, Holandino, C. Looking for a new biotherapic prepared from infectious influenza virus: an in vitro study. Proceedings of the $63^{\text {rd }}$ LMHI World Congress; 2008 May 20-24; Oostende, Belgium. Paris: GIRI; 2008. $1-12$.

[10] Holandino C, Leal FD, Barcellos BO, Campos MA, Oliveira R, Veiga VF, Garcia, S, Zacharias, CR. Mechanical versus handmade succussions: a physical chemistry comparison. In: Bonamin LV, editor. Signals and Images II. Heidelberg (Deutschland): Springer; 2008. Part II, p 37-42.

[11] El Bacha TP, Sola-Penna M. Alterações no metabolismo de células neoplásicas, In: Da Poian AT, Carvalho-Alves PC, editors. Hormônios e metabolismo: integração e correlações clínicas. São Paulo: Editora Atheneu; 2002. 319-322.

[12] Meira, DD, Marinho-Carvalho MM, Teixeira CA, Veiga VF, Da Poia AT, Holandino, C, Freitas,
MS, Sola-Penna, M. Clotrimazole decreases human breast cancer cells viability through alterations in cytoskeleton-associated glycolitic enzymes. Mol Genet Metab. 2005; 84: 354-62.

[13] Greiner EF, Guppy M, Brandy K. Glucose is essential for proliferation and the glycolitc enzyme induction that provokes a transition to glycolytic energy production. J Biol Chem. 1994; 269: 3148431490.

[14] Brazilian Homeopathic Pharmacopeia. $2^{\circ}$ ed, vol 1. São Paulo: Atheneu; 1997.

[15] Holandino C, Veiga VF, Capella MAM, Menezes $\mathrm{S}$, Alviano CS. Damage induction by direct electric current in tumoral target cells (P815). Indian J Exp Biol. 2000; 38: 554-558.

[16] Aquino CL, Varricchio MCBN, Pereira C, Moreno G, Sales FC, Santos TCF, Zancan P, SolaPenna M, Holandino C. Antitumoral activity of ultra diluted solutions of Euphorbia tirucalli Lineu: an in vitro study. Cultura Homeopática. 2006; 16:54.

[17] Mosmann T. Rapid colorimetric assay for cellular growth and survival: application to proliferation and cytotoxic assays. J Immunol Methods. 1983; 65: 55-63.

[18] Veiga VF, Nimrichter L, Teixeira CA, Morales MM, Alviano CS, Rodrigures ML, Holandino C. Exposure of human leukemic cells to direct electric current: generation of toxic compounds inducing cell death by different mechanisms. Cell Biochem Biophys. 2005; 42: 61-74.

[19] Sola-Penna M, Santos AC, Alves GG, El-Bacha T, Faber-Barata G, Pereira MF, Serejo FC, Da Poian AT, Sorenson M. A radioassay for phosphofructokinase-1 activity in cell extracts and purified enzyme. J Biochem Biophys Methods. 2002; 50: 129-140.

[20] Veiga VF, Holandino C, Rodrigues ML, Capella MA, Menezes S, Alviano CS. Cellular damage and altered carbohydrate expression in P815 tumor cells induced by direct electric current: an in vitro analysis. Bioelectromagnetics. 2000; 21: 597-607.

\section{(c) BY-NC-ND Licensed to GIRI}

Support: FAPERJ, FUJB, $\overline{\mathrm{CNPq}}$

Conflict of interest: authors declare there is no conflict of interest

Received: 25 June 2008; Revised 01 September 2008; Published: 15 September 2008

Erratum: 30 Dec 2008. (http://www.feg.unesp.br/ ojs/zacha_ijhdr/erratum/?v=7\&i=24\&pi=132)

Correspondence author: Carla Holandino Quaresma, cholandino@yahoo.com

How to cite this article: Aquino CL, Barbosa GM, Barbosa GM, Varricchio MCBA, Veiga VF, Kuster R, Zancan P, SolaPenna M, Quaresma CH. High dilutions of Euphorbia tirucalli L. (AVELOZ) modify the viability and glycolytic metabolism of cell lines. Int J High Dilution Res [online]. 2008 [cited YYYY Mmm DD]; 7(24): 132-139. Available from: http://www.feg.unesp.br/ ojs/index.php/ijhdr/article/view/283/361. 